\title{
Utilization of in Vitro Anther Culture in Spelt Wheat Breeding
}

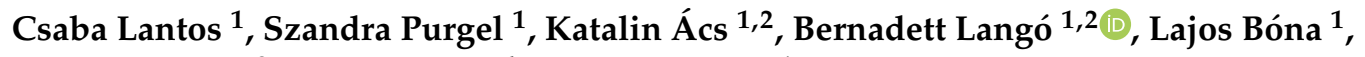 \\ Krisztina Boda ${ }^{3}$, Ferenc Békés ${ }^{4}$ and János Pauk ${ }^{1, *}$ \\ 1 Cereal Research Non-profit Ltd., P.O. Box 391, H-6701 Szeged, Hungary; \\ csaba.lantos@gabonakutato.hu (C.L.); szandra.purgel@gabonakutato.hu (S.P.); \\ katalin.acs@gabonakutato.hu (K.Á.); bernadett.lango@gabonakutato.hu (B.L.); \\ lajos.bona@gabonakutato.hu (L.B.) \\ 2 George Oláh PhD School, Budapest University of Technology and Economics, 1521 Budapest, Hungary \\ 3 Department of Medical Physics and Informatics, University of Szeged, Korányi fasor 9, \\ Szeged 6720, Hungary; boda.krisztina@med.u-szeged.hu \\ 4 FBFD PTY LTD., Hull Road 34, Beecroft, NSW 2119, Australia; firinc47@gmail.com \\ * Correspondence: janos.pauk@gabonakutato.hu; Tel.: +36-62-435-235
}

Received: 23 September 2019; Accepted: 20 October 2019; Published: 22 October 2019

\begin{abstract}
The efficiency of in vitro anther culture was screened in a full diallel population of four spelt wheat genotypes and ten $\mathrm{F}_{1}$ hybrids. Genotype dependency was observed based on the data of embryo-like structures (ELS), green-, albino plantlets. In the diallel population and ten $\mathrm{F}_{1}$ hybrids, the green plantlets production ranged from 13.75 to 85.00 and from 6.30 to 51.00, respectively. The anther culture-derived plants of $F_{1}$ hybrids were grown up in the nursery. At the harvest, 436 spontaneous doubled haploid (DH) plants were identified among the 1535 anther culture-derived transplanted and grown up individual plants. The mean of spontaneous rediploidization was $28.4 \%$ which ranged from $9.76 \%$ to $54.24 \%$. In two consecutive years, the agronomic values of 'Tonkoly.pop1' advanced line were compared with seven DH lines of 'Tonkoly.pop1' in the nursery. The DH lines achieved competitive values in comparison with 'Tonkoly.pop1' advanced line based on the 11 measured parameters (heading date, plant height, yield, hardness, width and length of seed, TKW, hulling yield, flour yield, protein and wet gluten content). These observations presage the efficient utilization of anther culture in spelt wheat breeding.
\end{abstract}

Keywords: in vitro androgenesis; anther culture; breeding; diallel analyses; haploid induction; spelt wheat

\section{Introduction}

In the last two decades, due to some special advantageous agronomic traits, i.e., wide adaptability, tillering ability, abiotic stress tolerance, and high biomass, the growing area of spelt wheat increased year by year [1-4]. In the organic farming system, spelt wheat is an attractive species because of the above-mentioned traits. Spelt is a competitive plant species against weeds due to their high tillering ability. Spelt has good adaptation to unfavourable soil conditions with low inputs. Furthermore, the interest in spelt wheat is increasing in human consumption because of the numerous benefits such as high content of protein, minerals $(\mathrm{Zn}, \mathrm{Cu}, \mathrm{Fe})$, and other bioactive compounds such as dietary fibres, phenolic compounds, phytosterols, and vitamins [3,5-10].

Spelt wheat is also grown in the marginal regions of wheat growing area. Implicitly, the capacity of spelt breeding was mitigated in comparison with bread wheat programs in the last period. So, there are many challenges (improvement of lodging resistance, fragile spike, earliness, and yield improvement) 
in the growing and breeding of spelt wheat to increase the economy of cultivation and produce marketable products $[2,4,11]$.

Recently, many modern approaches exist for breeders which can reduce the long process of breeding and increase the efficiency of breeding programs. The doubled haploid (DH) plant production belongs to these modern biotechnology methods of plant breeding [12-17]. The main advantage of DH plant production methods is the development of completely homozygous lines in one generation, while in conventional breeding programs the development of homozygous lines requires more generations. Recessive alleles can be identified and fixed using DH methods in early steps of the breeding process. The DH plant production methods can be combined with other breeding strategies such as mutation or transgenic technologies $[18,19]$.

Homogeneity is one of the essential requirements in the breeding of varieties and hybrids. Homozygous lines can be produced within one generation using biotechnological methods. Well-established DH plant production methods are applicable for breeding and research of some crop plants, for example: Barley, wheat, triticale, maize, and rice [12-15]. In spite of these benefits, only a few published data can be found in connection with DH plant production of spelt wheat [20-24].

In crop plants, there are three frequently applied DH plant production methods, namely chromosome elimination, anther culture, and isolated microspore culture. In haploid induction of spelt wheat, the chromosome elimination was reported by Escarnot et al. in 2014 [21]. However, because of low efficiency (16.1 embryos/100 pollinated florets and 38 plantlets/100 embryos) this method has not been applied for practical breeding, yet. The isolated microspore culture method is an effective and time-saving method, for example in barley and rapeseed [13,25-27]. This method was also tested with four spelt wheat genotypes but the albinism hindered the efficiency of green plant regeneration, the method required further improvements [23], yet. Anther culture was mentioned at first by Schmid in 1990 [20], the average of anther culture-derived plantlets was 0.9 plants/100 anthers in that experiment. Takács et al. [28] also reported the induction of in vitro androgenesis in anther culture of a single genotype (the number of responsive anthers was $6.4 \%$ ). Unfortunately, these promising results were inadequate for practical breeding programs.

Recently, the anther culture has proven to be an efficient method via four spelt genotypes ('Franckenkorn', 'GK Fehér', 'Mv Martongold', 'Oberkulmer Rotkorn'), the green plantlets production ranged from 20.93 to 83.08 green plantlets/100 anthers depending on genotype [23]. Some Spanish and Central European spelt genotypes were also tested in anther culture; the green plant production (1.8-15.6 green plants/100 anthers) was influenced by genotype [24]. However, a high number of albinos was regenerated from the anther culture-derived embryo-like structures (ELS) of these genotypes, the phenomenon of albinism limited the efficiency of anther culture [24].

In this study, our purposes were to screen the responsivity of a range of spelt genotypes in anther culture and verify the efficient application of $\mathrm{DH}$ plant production in the breeding procedure of this species. A diallel population of four spelt wheat genotypes and ten breeding targeted $\mathrm{F}_{1}$ hybrids was involved in the experiments. The data of the produced ELS, green-, and albino plantlets was collected and analysed. The percentage of spontaneous rediploidization was calculated based on the seed production of anther culture-derived plants of ten $\mathrm{F}_{1}$ hybrids. The agronomic values (heading date, plant height, yield, hardness, width and length of seed, TKW, hulling yield, milling yield, protein- and wet gluten content) of selected seven DH lines were monitored based on data of field experiment in two consecutive years.

\section{Results}

\subsection{In Vitro Androgenesis in Anther Culture of Spelt Wheat Full Diallel Population}

The in vitro androgenesis was induced in the anther culture of each of the tested genotypes, the genotype influenced the efficiency of the method. The number of ELS ranged from 32.75 to 173.33 ELS/100 anthers depending on genotype (Table 1). 
Table 1. Mean of embryo-like structures (ELS) production anther culture of a full diallel spelt wheat population. Values with the same capital letters are not significantly different $(p>0.05)$.

\begin{tabular}{cccccc}
\hline \multirow{2}{*}{ Genotype } & \multicolumn{4}{c}{ Male Parent } \\
\cline { 3 - 5 } & & 'Oberkulmer Rotkorn' & 'Martongold' & 'Franckenkorn' & 'GK Fehér' \\
\hline \multirow{3}{*}{ Female } & 'Oberkulmer Rotkorn' & $51.00 \mathrm{~b}$ & $50.50 \mathrm{~b}$ & $163.75 \mathrm{ab}$ & $120.33 \mathrm{ab}$ \\
Parent & 'Martongold' & $35.25 \mathrm{~b}$ & $34.25 \mathrm{~b}$ & $76.00 \mathrm{~b}$ & $82.25 \mathrm{ab}$ \\
& 'Franckenkorn' & $97.00 \mathrm{ab}$ & $155.00 \mathrm{ab}$ & $149.50 \mathrm{ab}$ & $82.75 \mathrm{ab}$ \\
& 'GK Fehér' & $74.25 \mathrm{~b}$ & $32.75 \mathrm{~b}$ & $173.33 \mathrm{a}$ & $88.33 \mathrm{ab}$ \\
\hline
\end{tabular}

The green plantlets production ranged from 13.75 to 85.00 green plantlets/100 anthers depending on genotype (Table 2). The highest value was achieved with the 'Franckenkorn'/'Martongold' hybrid. In anther culture of two hybrids ('Franckenkorn'/'Martongold' and 'Oberkulmer Rotkorn'/'Franckenkorn'), these values were significantly higher in comparison with their lower responding parents, respectively.

Table 2. Mean of green plantlets in anther culture of a full diallel spelt wheat population. Values with the same capital letters are not significantly different $(p>0.05)$.

\begin{tabular}{cccccc}
\hline \multirow{2}{*}{ Genotype } & \multicolumn{4}{c}{ Male Parent } \\
\cline { 3 - 6 } & & 'Oberkulmer Rotkorn' & 'Martongold' & 'Franckenkorn' & 'GK Fehér' \\
\hline \multirow{3}{*}{ Female } & 'Oberkulmer Rotkorn' & $20.75 \mathrm{c}$ & $24.00 \mathrm{c}$ & $56.25 \mathrm{ab}$ & $44.67 \mathrm{bc}$ \\
Parent & 'Martongold' & $19.50 \mathrm{c}$ & $19.00 \mathrm{c}$ & $35.00 \mathrm{bc}$ & $38.50 \mathrm{bc}$ \\
& 'Franckenkorn' & $40.50 \mathrm{bc}$ & $85.00 \mathrm{a}$ & $65.00 \mathrm{ab}$ & $36.25 \mathrm{bc}$ \\
& 'GK Fehér' & $29.25 \mathrm{bc}$ & $13.75 \mathrm{c}$ & $54.67 \mathrm{~b}$ & $33.00 \mathrm{bc}$ \\
\hline
\end{tabular}

The phenomenon of albinism was mitigated in anther culture of spelt wheat genotypes (Table 3). The number of produced albino plantlets ranged from 0 to 15 albinos/100 anthers depending on genotype. These values of two hybrids ('Franckenkorn'/'Martongold' and 'Franckenkorn'/'GK Fehér') were significantly lower in comparison with albino plantlets production of 'Franckenkorn'.

Table 3. Mean of albinos in anther culture of a full diallel spelt wheat population. Values with the same capital letters are not significantly different $(p>0.05)$.

\begin{tabular}{lccccc}
\hline \multirow{2}{*}{ Genotype } & \multicolumn{4}{c}{ Male Parent } \\
\cline { 3 - 6 } & & 'Oberkulmer Rotkorn' & 'Martongold' & 'Franckenkorn' & 'GK Fehér' \\
\hline \multirow{3}{*}{ Female } & 'Oberkulmer Rotkorn' & $1.25 \mathrm{~b}$ & $1.50 \mathrm{~b}$ & $10.75 \mathrm{ab}$ & $8.00 \mathrm{ab}$ \\
Parent & 'Martongold' & $2.75 \mathrm{~b}$ & $0.00 \mathrm{~b}$ & $6.00 \mathrm{~b}$ & $4.25 \mathrm{~b}$ \\
& 'Franckenkorn' & $9.25 \mathrm{ab}$ & $5.00 \mathrm{~b}$ & $15.00 \mathrm{a}$ & $5.25 \mathrm{~b}$ \\
\hline
\end{tabular}

Based on statistical analyses, the genotype influenced significantly the number of produced ELS, green-, and albino plantlets (Table 4). The effects of general combining ability (GCA) were also significant for each tested parameter. Significant reciprocal effect was measured in the number of regenerated green plantlets (Table 5). GCA effects were significant for each parameter of 'Martongold', 'Franckenkorn', and green plantlets of 'Oberkulmer Rotkorn' (Table 6).

Table 4. Analyses of variance for number of ELS, green-, and albino plantlets.

\begin{tabular}{ccccc}
\hline Source & DF & \multicolumn{3}{c}{ Mean Squares } \\
\cline { 3 - 5 } & & ELS & Green Plantlets & Albinos \\
\hline Replications & 3 & 2656.625 & 99.79 & 11.875 \\
Genotype & 15 & $9088.233 * * *$ & $1465.384 * * *$ & $64.967 * * *$ \\
Error & 45 & $2,117.103$ & 236.415 & 18.353 \\
Total & 63 & & \\
\hline
\end{tabular}


Table 5. Analyses of partitioned genotypic variance for ELS, green-, and albino plantlets.

\begin{tabular}{|c|c|c|c|c|}
\hline \multirow[t]{2}{*}{ Source } & \multirow[t]{2}{*}{ DF } & \multicolumn{3}{|c|}{ Mean Squares } \\
\hline & & ELS & Green Plantlets & Albinos \\
\hline GCA & 3 & $6699.7^{* *}$ & $963.34 * *$ & $51.786^{* *}$ \\
\hline SCA & 6 & 356.5 & 104.53 & 12.529 \\
\hline Reciprocals & 6 & 1973.8 & $330.28^{*}$ & 2.182 \\
\hline Error & 45 & 529.2 & 59.10 & 4.588 \\
\hline
\end{tabular}

Table 6. General combining ability (GCA) effects for ELS, green-, and albino plantlets in a full diallel spelt population.

\begin{tabular}{cccc}
\hline Varieties & ELS & Green Plantlets & Albinos \\
\hline 'Oberkulmer Rotkorn' & -11.25 & $-6.4844^{* *}$ & -0.5937 \\
'Martongold' & $-29.0937^{* *}$ & $-6.7344^{* *}$ & $-2.8750^{* * *}$ \\
'Franckenkorn' & $39.2188^{* * *}$ & $16.2656^{* * *}$ & $3.2813^{* * *}$ \\
'GK Fehér' & 1.125 & -3.0469 & 0.1875 \\
\hline ***** t-test is significant $p<0.01, p<0.001$, respectively; this effect is significantly different from zero
\end{tabular}

${ }^{* *},{ }^{* * *}$ t-test is significant $p<0.01, p<0.001$, respectively; this effect is significantly different from zero.

Some specific combining ability (SCA) effects differed significantly from zero for green ('Martongold'/'Franckenkorn') and albino ('Franckenkorn'/'GK Fehér') plantlets (Table 7).

Table 7. Specific combining ability (SCA) effects for (a) embryoid, (b) green-, and (c) albino plantlets.

\begin{tabular}{cccc}
\hline a, Genotype & 'Martongold' & 'Franckenkorn' & 'GK Fehér' \\
\hline 'Oberkulmer Rotkorn' & -8.40625 & 10.78125 & 15.75 \\
'Martongold' & & 13.75 & -6.15625 \\
'Franckenkorn' & & & -3.96875 \\
\hline b, Genotype & 'Martongold' & 'Franckenkorn' & 'GK Fehér' \\
\hline 'Oberkulmer Rotkorn' & -3.48438 & 0.150875 & 8.057625 \\
'Martongold' & & $12.01563^{* *}$ & -2.53663 \\
'Franckenkorn' & & & -6.19238 \\
\hline c, Genotype & 'Martongold' & 'Franckenkorn' & 'GK Fehér' \\
\hline 'Oberkulmer Rotkorn' & 0.09375 & 1.8125 & 1.15625 \\
'Martongold' & & -0.40625 & 0.0625 \\
'Franckenkorn' & & & $-4.343755^{* *}$ \\
\hline
\end{tabular}

** Significant at $p<0.01$.

After the rooting of the in vitro green plantlets, the green ones were acclimatized in the greenhouse. In October, the acclimatized plants were transplanted and grown up in the nursery. The seeds of spontaneous DH plants were harvested only and propagated in further tests and analysed of the spelt breeding program.

\subsection{Efficiency of Anther Culture in Ten Breeding Orientated $F_{1}$ Genotypes of Spelt Wheat}

The efficiency of anther culture was also tested in the anther culture of ten $\mathrm{F}_{1}$ breeding materials. Androgenesis was induced in each of the tested genotypes. The isolated anthers contained uninucleate microspores at the induction of in vitro androgenesis (Figure 1a). The ELS were visible to the naked eye on the fourth week of anther culture (Figure 1b). Genotype influenced significantly the number of 
ELS, in vitro green and albino plantlets (Table 8). The means of ELS production ranged from 19.5 to 183.47 ELS/100 anthers.

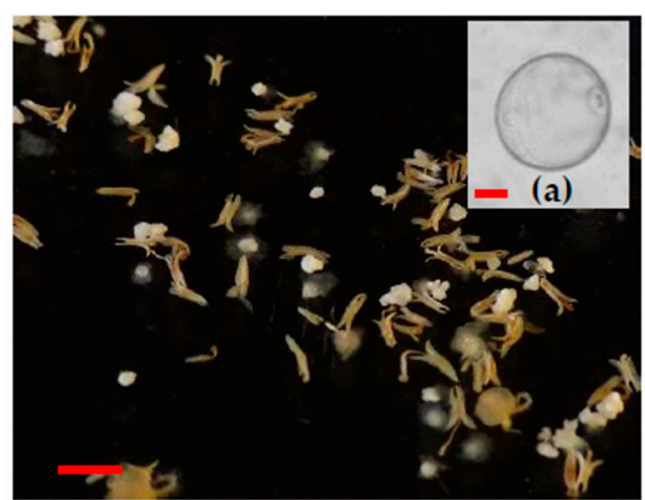

(b)

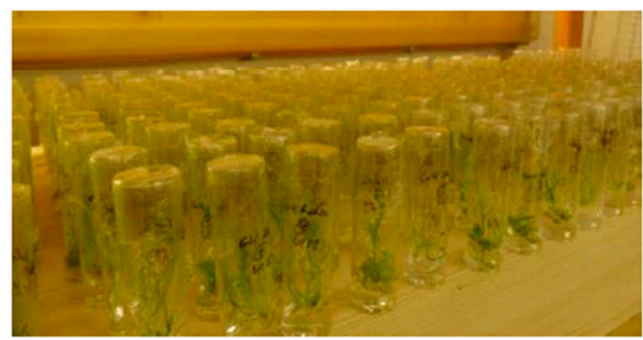

(d)

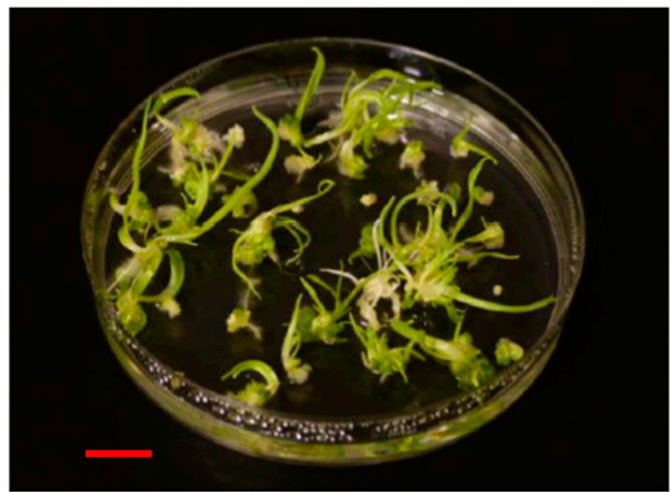

(c)

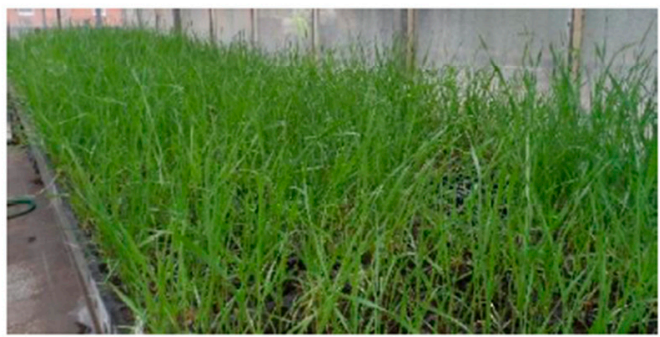

(e)

Figure 1. (a) Uninucleate microspores at the induction of androgenesis (bar $=10 \mu \mathrm{m}$ ). (b) Microspore-derived ELS developed in anther culture after four weeks of cultivation (bar $=5 \mathrm{~mm}$ ).

(c) The ELS produced green- and albino plantlets on the regeneration medium (bar $=10 \mathrm{~mm}$ ).

(d) The green plantlets were rooted in individual glass tubes, (e) which acclimatized to the greenhouse conditions.

Table 8. Efficiency of anther culture in ten breeding-orientated $F_{1}$ spelt genotypes. Values with the same capital letters are not significantly different $(p>0.05)$.

\begin{tabular}{cccc}
\hline Genotype & $\begin{array}{c}\text { Number of ELS/ } \\
\text { 100 Anthers }\end{array}$ & $\begin{array}{c}\text { Number of Albinos/ } \\
\text { 100 Anthers }\end{array}$ & $\begin{array}{c}\text { Number of Green } \\
\text { Plantlets/100 Anthers }\end{array}$ \\
\hline Spc24 & $110.60 \mathrm{ab}$ & $4.60 \mathrm{~b}$ & $39.80 \mathrm{ab}$ \\
Spc28 & $163.60 \mathrm{ab}$ & $4.20 \mathrm{~b}$ & $51.00 \mathrm{a}$ \\
Spc31 & $183.47 \mathrm{a}$ & $17.60 \mathrm{ab}$ & $37.20 \mathrm{ab}$ \\
Spc34 & $98.80 \mathrm{~b}$ & $8.10 \mathrm{~b}$ & $35.40 \mathrm{~b}$ \\
Spc36 & $66.20 \mathrm{bc}$ & $11.70 \mathrm{~b}$ & $14.30 \mathrm{c}$ \\
Spc39 & $109.20 \mathrm{~b}$ & $24.30 \mathrm{a}$ & $17.30 \mathrm{c}$ \\
Spc40 & $55.30 \mathrm{bc}$ & $9.10 \mathrm{~b}$ & $6.30 \mathrm{c}$ \\
Spc42 & $169.20 \mathrm{ab}$ & $22.27 \mathrm{a}$ & $25.73 \mathrm{bc}$ \\
Spc43 & $19.50 \mathrm{c}$ & $4.20 \mathrm{~b}$ & $8.40 \mathrm{c}$ \\
Spc50 & $126.10 \mathrm{ab}$ & $8.20 \mathrm{~b}$ & $47.40 \mathrm{ab}$ \\
\hline Mean & 110.20 & 11.43 & 28.28 \\
\hline LSD5\% & 73.29 & 8.17 & 14.51 \\
\hline
\end{tabular}

The ELS produced dominantly green plantlets within two weeks on the regeneration medium (Figure 1c). The green plantlets production was influenced by genotype (6.3-51.00 green plantlets/ 100 anthers). The mean of the in vitro regenerated green plantlets was 28.28 green plantlets/100 anthers. The phenomenon of albinism was observed, on average 4.2-24.3 albinos/100 anthers were regenerated 
from the ELS depending on genotype. In this experiment, the mean of the albino plantlets production was 11.43 albinos/100 anthers (Table 8).

The in vitro green plantlets were rooted in individual glass tubes (Figure 1d), and the well-rooted plantlets acclimatized to the greenhouse conditions (Figure 1e). The anther culture-derived plants were transplanted in the DH garden of the nursery in October. Altogether, 1535 transplanted plants were grown up until harvest in the nursery. In the DH garden, 436 fertile spelt wheats were identified among the transplanted plants based on the seed production (Table 9). The values of spontaneous rediploidization ranged from $9.76 \%$ to $54.24 \%$ depending on genotype. The mean of the spontaneous rediploidizaton was $28.40 \%$.

Table 9. Percentage of spontaneous rediploidization in spelt genotypes.

\begin{tabular}{cccc}
\hline Genotype & $\begin{array}{c}\text { Number of } \\
\text { Transplanted Plantlets }\end{array}$ & $\begin{array}{c}\text { Number of Fertile } \\
\text { Plants (DH) }\end{array}$ & $\begin{array}{c}\text { Percentage of Spontaneous } \\
\text { Rediploidization }\end{array}$ \\
\hline Spc24 & 216 & 42 & $19.44 \%$ \\
Spc28 & 306 & 68 & $22.22 \%$ \\
Spc31 & 144 & 33 & $22.91 \%$ \\
Spc34 & 168 & 67 & $39.88 \%$ \\
Spc36 & 41 & 4 & $9.76 \%$ \\
Spc39 & 153 & 83 & $54.24 \%$ \\
Spc40 & 17 & 5 & $29.41 \%$ \\
Spc42 & 126 & 52 & $41.27 \%$ \\
Spc43 & 52 & 23 & $44.23 \%$ \\
Spc50 & 312 & 59 & $18.91 \%$ \\
\hline Mean & 1535 & 436 & $28.40 \%$ \\
\hline
\end{tabular}

\subsection{Evaluation of in Vitro Generated Spelt Wheat DH Lines}

'Tonkoly.pop1' spelt wheat advanced line as a control and its seven different DH sister lines were compared in the nursery (Table 10). The DH lines showed uniform performance in the field (data not shown). The DH lines achieved similar values than the control in the heading date, plant height, and yield values. The effect of year caused bigger differences on the data of the three measured traits than the effect of genotype.

Table 10. Heading date, plant height, and yield parameters of 'Tonkoly.pop1' advanced line (Control) and its doubled haploid (DH) lines based on field experiment in two consecutive years. Values with the same capital letters are not significantly different $(p>0.05)$.

\begin{tabular}{ccccccc}
\hline \multirow{2}{*}{ Genotype } & \multicolumn{2}{c}{ Heading Date } & \multicolumn{2}{c}{ Plant Height (cm) } & \multicolumn{2}{c}{ Yield (t/ha) } \\
\cline { 2 - 6 } & $\mathbf{2 0 1 7 / 1 8}$ & $\mathbf{2 0 1 8 / 1 9}$ & $\mathbf{2 0 1 7 / 1 8}$ & $\mathbf{2 0 1 8 / 1 9}$ & $\mathbf{2 0 1 7 / 1 8}$ & $\mathbf{2 0 1 8 / 1 9}$ \\
\hline DH1 & $141 \mathrm{ab}$ & $147 \mathrm{c}$ & $115 \mathrm{ab}$ & $120 \mathrm{a}$ & $5.06 \mathrm{ab}$ & $5.95 \mathrm{~b}$ \\
DH2 & $141 \mathrm{ab}$ & $147 \mathrm{c}$ & $115 \mathrm{ab}$ & $120 \mathrm{a}$ & $4.74 \mathrm{ab}$ & $5.86 \mathrm{~b}$ \\
DH3 & $142 \mathrm{ab}$ & $147 \mathrm{c}$ & $115 \mathrm{ab}$ & $125 \mathrm{~b}$ & $4.85 \mathrm{ab}$ & $5.85 \mathrm{~b}$ \\
DH4 & $143 \mathrm{~b}$ & $147 \mathrm{c}$ & $110 \mathrm{a}$ & $125 \mathrm{~b}$ & $4.19 \mathrm{a}$ & $5.38 \mathrm{ab}$ \\
DH5 & $142 \mathrm{ab}$ & $147 \mathrm{c}$ & $115 \mathrm{ab}$ & $125 \mathrm{~b}$ & $4.43 \mathrm{a}$ & $6.09 \mathrm{~b}$ \\
DH6 & $143 \mathrm{~b}$ & $147 \mathrm{c}$ & $110 \mathrm{a}$ & $115 \mathrm{ab}$ & $4.34 \mathrm{a}$ & $6.18 \mathrm{~b}$ \\
DH7 & $141 \mathrm{ab}$ & $147 \mathrm{c}$ & $110 \mathrm{a}$ & $125 \mathrm{~b}$ & $4.24 \mathrm{a}$ & $6.79 \mathrm{~b}$ \\
Control & $140 \mathrm{a}$ & $147 \mathrm{c}$ & $115 \mathrm{ab}$ & $130 \mathrm{~b}$ & $4.37 \mathrm{a}$ & $6.13 \mathrm{~b}$ \\
\hline LSD5\% & \multicolumn{7}{c}{10.94} \\
\hline
\end{tabular}

Hulling yield, flour yield, and some selected chemical parameters were also evaluated (Table 11). The effect of year was significant on flour yield, protein content, and wet gluten content in both years in several genotypes. The genotype influenced significantly the measured data of hulling yield, protein 
content, and wet gluten content in both years. In flour yield, significant differences were observed among the genotypes only in the first year.

Table 11. Processing efficiency and some selected chemical parameters of 'Tonkoly.pop1' spelt wheat advanced line (Control) and its doubled haploid (DH) lines based on field experiment in two consecutive years. Values with the same capital letters are not significantly different $(p>0.05)$.

\begin{tabular}{ccccccccc}
\hline \multirow{2}{*}{ Genotype } & \multicolumn{2}{c}{ Hulling Yield \% } & \multicolumn{2}{c}{ Flour Yield \% } & \multicolumn{2}{c}{ Protein Content \% } & \multicolumn{2}{c}{ Wet Gluten Cont. \% } \\
\cline { 2 - 9 } & $\mathbf{2 0 1 7 / 1 8}$ & $\mathbf{2 0 1 8 / 1 9}$ & $\mathbf{2 0 1 7 / 1 8}$ & $\mathbf{2 0 1 8 / 1 9}$ & $\mathbf{2 0 1 7 / 1 8}$ & $\mathbf{2 0 1 8 / 1 9}$ & $\mathbf{2 0 1 7 / 1 8}$ & $\mathbf{2 0 1 8 / 1 9}$ \\
\hline DH1 & $67.6 \mathrm{~d}$ & $66.9 \mathrm{~cd}$ & $56.53 \mathrm{ab}$ & $60.94 \mathrm{bc}$ & $13.6 \mathrm{ab}$ & $16.0 \mathrm{bc}$ & $33.1 \mathrm{ab}$ & $35.1 \mathrm{bc}$ \\
DH2 & $66.0 \mathrm{bc}$ & $66.0 \mathrm{bc}$ & $54.00 \mathrm{a}$ & $61.45 \mathrm{bc}$ & $13.8 \mathrm{ab}$ & $16.1 \mathrm{bc}$ & $32.8 \mathrm{ab}$ & $35.2 \mathrm{bc}$ \\
DH3 & $67.6 \mathrm{~d}$ & $67.2 \mathrm{~cd}$ & $55.23 \mathrm{ab}$ & $60.96 \mathrm{bc}$ & $13.8 \mathrm{ab}$ & $16.1 \mathrm{bc}$ & $32.2 \mathrm{ab}$ & $35.1 \mathrm{bc}$ \\
DH4 & $66.3 \mathrm{c}$ & $66.2 \mathrm{bc}$ & $54.59 \mathrm{a}$ & $62.18 \mathrm{c}$ & $14.0 \mathrm{ab}$ & $15.3 \mathrm{bc}$ & $32.3 \mathrm{ab}$ & $32.9 \mathrm{ab}$ \\
DH5 & $67.9 \mathrm{~d}$ & $67.2 \mathrm{~cd}$ & $58.28 \mathrm{~b}$ & $61.69 \mathrm{c}$ & $13.6 \mathrm{ab}$ & $15.1 \mathrm{~b}$ & $31.4 \mathrm{a}$ & $31.8 \mathrm{ab}$ \\
DH6 & $65.7 \mathrm{bc}$ & $66.0 \mathrm{bc}$ & $57.05 \mathrm{ab}$ & $62.68 \mathrm{c}$ & $13.0 \mathrm{a}$ & $15.1 \mathrm{~b}$ & $30.5 \mathrm{a}$ & $31.7 \mathrm{ab}$ \\
DH7 & $63.4 \mathrm{a}$ & $64.1 \mathrm{ab}$ & $54.84 \mathrm{a}$ & $59.71 \mathrm{bc}$ & $13.3 \mathrm{a}$ & $15.8 \mathrm{bc}$ & $30.3 \mathrm{a}$ & $34.4 \mathrm{~b}$ \\
Control & $65.6 \mathrm{bc}$ & $65.0 \mathrm{~b}$ & $56.5 \mathrm{ab}$ & $62.68 \mathrm{c}$ & $16.2 \mathrm{bc}$ & $16.8 \mathrm{c}$ & $35.1 \mathrm{bc}$ & $37.4 \mathrm{c}$ \\
\hline LSD5\% & \multicolumn{3}{c}{1.2} & \multicolumn{3}{c}{3.4} & \multicolumn{3}{c}{1.59} & & 2.91 \\
\hline
\end{tabular}

Some physical parameters of the seeds were also compared in the two-year experiment (Table 12). Kernel hardness of DH lines (9-18) showed significant differences only in the second year, 'Tonkoly.pop1' advanced line, and its DH lines could be characterized with soft kernel type. Kernel width values varied in the narrow range, $2.27-2.55 \mathrm{~mm}$, also kernel length was between 7.01-7.44 mm, whilst TKW was between 28.8 and $34.7 \mathrm{~g}$ in the selected genotypes.

Table 12. Values of grain physical parameters of 'Tonkoly.pop1' spelt wheat advanced line (Control) and its doubled haploid $(\mathrm{DH})$ lines based on field experiments. Values with the same capital letters are not significantly different $(p>0.05)$.

\begin{tabular}{ccccccccc}
\hline \multirow{2}{*}{ Genotype } & \multicolumn{2}{c}{ Hardness (-) } & \multicolumn{2}{c}{ Width $\mathbf{( m m )}$} & \multicolumn{2}{c}{ Length $(\mathbf{m m})$} & \multicolumn{2}{c}{ TKW (g) } \\
\cline { 2 - 9 } & $\mathbf{2 0 1 7 / 1 8}$ & $\mathbf{2 0 1 8 / 1 9}$ & $\mathbf{2 0 1 7 / 1 8}$ & $\mathbf{2 0 1 8 / 1 9}$ & $\mathbf{2 0 1 7 / 1 8}$ & $\mathbf{2 0 1 8 / 1 9}$ & $\mathbf{2 0 1 7 / 1 8}$ & $\mathbf{2 0 1 8 / 1 9}$ \\
\hline DH1 & $16.0 \mathrm{ab}$ & $16.0 \mathrm{ab}$ & $2.350 \mathrm{a}$ & $2.48 \mathrm{a}$ & $7.14 \mathrm{~b}$ & $7.42 \mathrm{~d}$ & $31.3 \mathrm{a}$ & $32.8 \mathrm{a}$ \\
DH2 & $13.0 \mathrm{ab}$ & $9.0 \mathrm{a}$ & $2.390 \mathrm{a}$ & $2.49 \mathrm{a}$ & $7.19 \mathrm{~b}$ & $7.38 \mathrm{~cd}$ & $31.0 \mathrm{a}$ & $33.9 \mathrm{a}$ \\
DH3 & $16.0 \mathrm{ab}$ & $11.0 \mathrm{ab}$ & $2.420 \mathrm{a}$ & $2.48 \mathrm{a}$ & $7.2 \mathrm{~b}$ & $7.44 \mathrm{~d}$ & $32.3 \mathrm{a}$ & $33.2 \mathrm{a}$ \\
DH4 & $19.0 \mathrm{~b}$ & $14.0 \mathrm{ab}$ & $2.270 \mathrm{a}$ & $2.47 \mathrm{a}$ & $7.15 \mathrm{~b}$ & $7.4 \mathrm{~cd}$ & $29.8 \mathrm{a}$ & $33.4 \mathrm{a}$ \\
DH5 & $17.0 \mathrm{~b}$ & $13.0 \mathrm{ab}$ & $2.370 \mathrm{a}$ & $2.55 \mathrm{a}$ & $7.2 \mathrm{~b}$ & $7.35 \mathrm{c}$ & $31.0 \mathrm{a}$ & $34.6 \mathrm{a}$ \\
DH6 & $18.0 \mathrm{~b}$ & $14.0 \mathrm{ab}$ & $2.290 \mathrm{a}$ & $2.48 \mathrm{a}$ & $7.11 \mathrm{ab}$ & $7.39 \mathrm{~cd}$ & $28.8 \mathrm{a}$ & $33.4 \mathrm{a}$ \\
DH7 & $14.0 \mathrm{ab}$ & $18.0 \mathrm{~b}$ & $2.340 \mathrm{a}$ & $2.53 \mathrm{a}$ & $7.1 \mathrm{ab}$ & $7.31 \mathrm{c}$ & $30.2 \mathrm{a}$ & $34.7 \mathrm{a}$ \\
Control & $18.00 \mathrm{~b}$ & $17.0 \mathrm{~b}$ & $2.495 \mathrm{a}$ & $2.34 \mathrm{a}$ & $7.01 \mathrm{a}$ & $7.21 \mathrm{bc}$ & $32.4 \mathrm{a}$ & $29.5 \mathrm{a}$ \\
\hline LSD5\% & \multicolumn{7}{c}{0.28} & \multicolumn{2}{c}{0.104} & 5.9 \\
\hline
\end{tabular}

\section{Discussion}

Although the methods of plant biotechnology play a key role in modern plant breeding, a few published data are available in connection with in vitro androgenesis of spelt wheat especially from the viewpoint of practical breeding. A full diallel crossing program was carried out with the four varieties ('Franckenkorn', 'GK Fehér', 'Mv. Martongold', and 'Oberkulmer Rotkorn'). Furthermore, ten breeding targeted $F_{1}$ genotypes were involved in our research and breeding program. In $F_{1}$ generation of twenty-two spelt wheat combinations, in vitro anther culture method was tested to produce genetically pure lines for spelt breeding program [22,23,29].

In monocots, some relevant publications reported the genotype dependency and albinism as a bottlenecks of in vitro androgenesis which prohibited the practical application of anther culture in the breeding of more cereal species [12,15,24,30-34]. At the early period of in vitro androgenesis research, 
the published protocols were not effective for practical spelt breeding programs $[20,28]$. Recently, anther culture methods have been published as an efficient tool for DH plant production in some spelt genotypes $[23,24]$. However, the phenomenon of albinism was also mentioned as a limiting factor of anther culture in some experiments [23].

The genotype influenced significantly the efficiency of anther culture in common wheat [35-37], and the genotype effect was also published in anther culture of spelt wheat genotypes $[20,23,24]$. Both reciprocal and nuclear genetic effects were observed in anther culture of common wheat [37]. However, GCA effects were more determinative than the SCA effects for the anther culture parameters [37]. According to relevant publications, the inheritance of anther culture response is determined dominantly by additive genetic effects in common wheat $[37,38]$. In the present in vitro experiments, a full diallel crossing program and ten $\mathrm{F}_{1}$ hybrids were tested in vitro anther culture to clarify the efficiency of this method with a range of spelt genotypes. In vitro androgenesis was induced in each of the tested genotypes, although the genotype influenced significantly the efficiency of the method. In the full diallel population, high number of in vitro green plantlets was produced while the number of albinos was limited. The highest green plantlets production (65.00 green plantlets/100 anthers) was achieved by 'Franckenkorn' genotype among the parents similarly to our previous results [23], while 'Franckenkorn/Martongold' hybrid produced 85.00 in vitro green plantlets/100 anthers. Based on the statistical analyses, most of the genotypic variance was due to GCA effects; consequently additive genetic variance was a primary contributor to the observed data. Similar phenomenon was reported in common wheat $[37,38]$. This observation prohibits the practical application of the anther culture in spelt wheat breeding and research.

The ten breeding targeted hybrids produced different quantity green plants depending on genotype. In the nursery, 436 fertile DH lines were identified among the 1535 transplanted plants. The percentage of spontaneous rediploidization was $28.4 \%$ which was also influenced by genotype (9.76-54.24\%). In our previous experiment, the percentage of spontaneous DH plants was $24.27 \%$ $(11.8-44.44 \%)$ based on data of four genotypes [23]. These values (15-80\%) were also influenced by genotype in an anther culture of Spanish and Central European spelt wheat genotypes [24]. In contrast with some critical reviews $[12,15,24,30-34]$, the anther culture was an efficient method for the tested spelt genotypes.

'Tonkoly.pop1' advanced line and its seven different DH sister lines were compared in the two-year field experiment. First of all, the spelt wheat DH lines showed uniform performance in the field which is a critical viewpoint in breeding. The DH lines showed competitive values based on their 11 measured parameters (heading date, plant height, yield, hardness, width and length of seed, TKW, hulling yield, flour yield, protein content, wet gluten content) in comparison with the control. In the case of several traits of DH lines, the genotype influenced significantly the measured parameters in both years. Genetically independent DH lines were separated from the advanced line. So, these data emphasized the practical application of DH method in spelt breeding.

\section{Materials and Methods}

\subsection{Plant Materials}

Four winter type spelt varieties were selected for a full diallel analysis, these genotypes are popular and cultivated varieties in Hungary. 'GK Fehér' was released in 2017 by us at the Cereal Research Non-Profit Ltd., while the seeds of other varieties-'Franckenkorn', 'Mv Martongold', and 'Oberkulmer Rotkorn'-were supplied to us by the Agricultural Institute, Centre for Agricultural Research, Hungarian Academy of Sciences, Martonvásár, Hungary. A full diallel population (four parents and their 12 hybrids) was generated by crossing of the four spelt varieties. The parents and their $F_{1}$ hybrids were involved in the in vitro experiments. Furthermore, ten breeding targeted $\mathrm{F}_{1}$ combinations were also tested in vitro anther culture (Table 13). The parents of the $\mathrm{F}_{1}$ combinations were cultivated varieties ('Franckenkorn', 'GK Fehér', 'Lajta', 'Martongold', 'Oberkulmer Rotkorn') in Hungary, 
advanced lines ('Aus', 'Bartucz') or germplasms from Hungarian national gene bank (Center for Plant Diversity's, Tápiószele: RCAT056296, RCAT058694, RCAT060960).

Table 13. The pedigree of $\mathrm{F}_{1}$ combinations tested in vitro anther culture.

\begin{tabular}{cc}
\hline Code Number & Genotype \\
\hline Spc24 & 'RCAT056296'//'GK Fehér'/'Franckenkorn' \\
Spc28 & 'RCAT058694'/'GK Fehér' \\
Spc31 & 'Aus'/'RCAT058694' \\
Spc34 & 'Aus'//Lajta' \\
Spc36 & 'Aus'/'GK Fehér' \\
Spc39 & 'Aus'/'RCAT056296' \\
Spc40 & 'Aus'/'Martongold' \\
Spc42 & 'Aus'/'Bartucz' \\
Spc43 & 'Aus'/'Oberkulmer Rotkorn' \\
Spc50 & 'RCAT060960'//'GK Fehér'/'Franckenkorn' \\
\hline
\end{tabular}

The donor plants of each genotype were grown in the greenhouse at Cereal Research Non-Profit Ltd., Szeged, Hungary. The vernalized plants were transplanted into 21 plastic pots which contained a 1:1 peat and sandy soil mix. Volldünger chemical fertilizer (N:P:K:Mg =14:7:21:1, plus 1\% microelements: $\mathrm{B}, \mathrm{Cu}, \mathrm{Fe}, \mathrm{Mn}$, and $\mathrm{Zn}$; produced by Magyar Kwizda Ltd., Budapest, Hungary) were used for fertilizing of the plants once in a fortnight. In the growing period, $20 / 15^{\circ} \mathrm{C}$ day/night temperature were adjusted for plants, respectively. Natural light was supplemented with $3 \mathrm{~h}$ artificial light until the collection of donor tillers. For proper plant growth, required fertilizers and fungicides were applied and weeds were removed manually.

\subsection{Preparation of Anther Cultures}

The donor tillers were collected when the microspores were in early- and mid-uninucleate stages. The developmental stages of microspores were checked by Olympus CK-2 inverted microscope (Olympus Ltd., Southend-on-Sea, UK). The collected donor tillers were placed into Erlenmeyer flasks containing tap water and covered by PVC bags to keep high humidity. The collected donor tillers were cold pre-treated at $3-4{ }^{\circ} \mathrm{C}$ for 14 days. After the cold pre-treatment, the spikes of the selected genotypes were sterilized in $300 \mathrm{ml} 2 \% \mathrm{NaOCl}$ solution with one drop Tween- 80 for 20 min on a shaker. The spikes were rinsed three times with distilled water (Millipore Elix 5) in laminar air flow.

From the prepared spikes, 300 anthers were isolated in each $90 \mathrm{~mm}$ diameter glass Petri dishes containing $12 \mathrm{ml}$ 'W14mf' induction medium [39,40]. On the first three days of culture, the Petri dish were incubated at $32{ }^{\circ} \mathrm{C}$ to apply heat shock treatment. The anther cultures were kept at $28^{\circ} \mathrm{C}$ for eight weeks in a dark thermostat.

\subsection{Plant Regeneration and Acclimatization of Anther Culture-Derived Green Plants}

The well-developed ELS with a size of 1-2 $\mathrm{mm}$ was transferred into $90 \mathrm{~mm}$ diameter plastic Petri dishes (Sarstedt, Newton, MA, USA) which contained the 190-2Cu medium [29]. The ELS regenerated green and albino plantlets on the regeneration medium. The albino plantlets were discarded while the green plantlets with two-three leaves were transferred into individual glass tubes which contained the '190-3Cu' regeneration medium for rooting [23].

The well-rooted green plantlets were transferred into the greenhouse. The plantlets were transplanted into plastic plates (66 plantlets/plate) which contained the above mentioned 1:1 soil mix. The plantlets were covered by transparent plastic cover during the 3-4 day-long acclimatization period. The acclimatized plants were grown in the greenhouse following the above-mentioned growing protocol for donor plants in the greenhouse. 


\subsection{Growing of Anther Culture-Derived Plants in DH Nursery}

The acclimatized anther culture-derived plants of the ten $\mathrm{F}_{1}$ hybrids were transplanted manually into the DH nursery in October 2018. The transplanted plantlets were irrigated as needed to support the development of roots and acclimatization of the plantlets to the field conditions. The seeds of the spontaneous DH plants were harvested from the fertile plants in July 2019.

\subsection{Field Study and Evaluation of Spelt Wheat DH Lines}

In preliminary experiments, DH lines of 'Tonkoly.pop1' advanced line were produced by anther culture. These $\mathrm{DH}$ lines were integrated into our breeding program. After $\mathrm{DH}_{1}$ generation, seven different individual DH lines of 'Tonkoly.pop1' were selected based on their phenotypic and agronomic data (data not shown). These selected seven DH lines along with the control ('Tonkoly.pop1' advanced line) were shown in our spelt wheat nursery $(40 \times 1 \mathrm{~m}$ plots each) in two consecutive years $(2017 / 2018$ and 2018/2019). These DH lines and the control were characterized by some agronomic and grain quality parameters (heading data, plant height, yield, hardness, width and length of seeds, thousand kernel weight (TKW), hulling yield\%, flour yield\%, wet gluten content) based on the collected data.

Kernel hardness, width, and TKW parameters were measured with a PERTEN SKCS 3100 (Perten Instruments, Sweden) according to the Approved Method [41]. Kernel length was measured with calipers. Protein and wet gluten content were detected by NIR (Mininfra SmarT, Infracont, Hungary). Samples were dehulled with Spelt Huller (Kapacitív Kkt., Hungary), hulling yield was calculated. Dehulled grains were conditioned to $14 \%$ moisture content overnight and milled by Brabender Quadromat Senior Mill (Brabender GmbH \& Co., Germany) to pass through a $250 \mu \mathrm{m}$ screen, flour yield was calculated.

\subsection{Statistical Analyses}

Our in vitro experiments were repeated at least three times, minimum $3 \times 300$ anthers were tested in each treatment. The three important parameters of in vitro androgenesis (number of ELS, in vitro green-, and albino plantlets) were collected and analysed by one-way ANOVA. The data of diallel population were used to determine combining abilities (GCA and SCA) and clarify the reciprocal and nuclear genetic effects in anther culture of spelt genotypes. GCA and SCA and reciprocal effects were analysed using Griffing's (1956) method 1, model 1 [42]. The percentage of spontaneous rediploidization was calculated based on seed production of anther culture-derived plants of ten $\mathrm{F}_{1}$ hybrids. In the field experiment, the measured data of seven DH lines and 'Tonkoly.pop1' advanced line were analysed by two-way ANOVA without repetition.

The statistical analyses were carried out using Microsoft Excel 2013 statistical software developed by Microsoft Ltd. (Redmond, WA, USA) and the statistical program SPSS (SPSS Hungary 1115 Budapest Bartók Béla Street 105-113).

\section{Conclusions}

The spelt wheat breeding program was initialized with a full diallel crossing of four genotypes and ten $\mathrm{F}_{1}$ hybrids. In vitro anther culture method was applied in $\mathrm{F}_{1}$ generation to support the breeding process. The genotype influenced significantly the androgenic parameters (number of ELS, green-, and albino plantlets). GCA effects were more determinative than the SCA effects in anther culture of the diallel population, anther culture response was determined dominantly by additive genetic effects. In the field experiment, seven anther culture-derived $\mathrm{DH}$ lines were tested in comparison with the control genotype. The $\mathrm{DH}$ lines were competitive with the control advanced line based on the 11 tested parameters. The anther culture method proved to be an efficient tool to produce lots of $\mathrm{DH}$ lines for breeding and applied research in spelt wheat.

Author Contributions: C.L. organized the implementation of experiments and wrote the manuscript; S.P. and L.B. carried out the two-year field experiments; K.Á. and B.L. analysed the quality of DH seed samples; K.B. analysed 
the GCA and SCA effects; F.B. guided the spelt flour quality research and J.P. planned the experiments, directed the project, and corrected the manuscript.

Funding: This research was funded by the Hungarian Academy of Sciences, grant number "János Bolyai Research Scholarship"; National Research, Development and Innovation Office, grant number "OTKA-K_16-K119835”, "GINOP-2.2.1-15-2016-00026" and "TUDFO/51757/2019-ITM.

Acknowledgments: This project was supported by the János Bolyai Research Scholarship of the Hungarian Academy of Sciences. The experiments were interlocked with scientific programme (project code: OTKA-K_16-K119835; name of project: Improvement of spelt wheat lines with low fermentable carbohydrate content (FODMAP) using modern and classical research methods), Thematic Excellence Programme 2019 (project code: TUDFO/51757/2019-ITM, supporter: National Research, Development and Innovation Office) and GINOP project (project number: GINOP-2.2.1-15-2016-00026). The authors thank the conscientious work of Krisztina Kéri, Ferenc Markó, and Sándor Vajasdi-Nagy. Furthermore, the authors also thank László Láng (Centre for Agricultural Research, Hungarian Academy of Sciences, Martonvásár, Hungary) and Center for Plant Diversity's (Tápiószele, gene bank of Hungary) to supply the cultivated varieties ('Franckenkorn', 'Mv Martongold' and 'Oberkulmer Rotkorn') and gene bank gemplasms (RCAT056296, RCAT058694, RCAT060960) for experiments, respectively.

Conflicts of Interest: The authors declare that they have no conflict of interest.

\section{References}

1. Raman, H.; Rahman, R.; Luckett, D.; Raman, R.; Bekes, F.; Lang, L.; Bedo, Z. Characterisation of genetic variation for aluminium resistance and polyphenol oxidase activity in genebank accessions of spelt wheat. Breed. Sci. 2009, 59, 373-381. [CrossRef]

2. Koutroubas, S.D.; Fotiadis, S.; Damalas, C.A. Biomass and nitrogen accumulation and translocation in spelt (Triticum spelta) grown in Mediterranean area. Field Crop Res. 2012, 127, 1-8. [CrossRef]

3. Arzani, A.; Ashraf, M. Cultivated Ancient Wheats (Triticum spp.): A potential source of health-beneficial food products. Compr. Rev. Food Sci. F. 2017, 16, 477-488. [CrossRef]

4. Andruszczak, S. Spelt wheat grain yield and nutritional value response to sowing rate and nitrogen fertilization. J. Anim. Plant Sci. 2018, 28, 1476-1484.

5. Fan, M.S.; Zhao, F.J.; Fairweather-Taitc, S.J.; Poultona, P.R.; Dunhama, S.J.; McGrath, S.P. Evidence of decreasing mineral density in wheat grain over the last 160 years. J. Trace Elem. Med. Biol. 2008, 22, 315-324. [CrossRef]

6. Zielinski, H.; Ceglinska, A.; Michalska, A. Bioactive compounds in spelt bread. Eur. Food Res. Technol. 2008, 226, 537-544. [CrossRef]

7. Gomez-Becerra, H.F.; Erdem, H.; Yazici, A.; Tutus, Y.; Torun, B.; Ozturk, L.; Cakmak, I. Grain concentration of protein and mineral nutrients in a large collection of spelt wheat grown under different environments. J. Cereal Sci. 2010, 52, 342-349. [CrossRef]

8. Escarnot, E.; Aguedo, M.; Agneessens, R.; Wathelet, B.; Paquot, M. Extraction and characterization of water-extractable and water-unextractable arabinoxylans from spelt bran: Study of the hydrolysis conditions for monosaccharides analyses. J. Cereal Sci. 2011, 53, 45-52. [CrossRef]

9. Guzman, C.; Medina-Larque, A.S.; Velu, G.; Gonzalez-Santoyo, H.; Singh, R.P.; Huerta-Espino, J.; Ortiz-Monasterio, I.; Pena, R.J. Use of wheat genetic resources to develop biofortified wheat with enhanced grain zinc and iron concentration and desirable processing quality. J. Cereal Sci. 2014, 60, 617-622. [CrossRef]

10. Hlisnikovsky, L.; Hejcman, M.; Kunzova, E.; Mensik, L. The effect of soil-climate conditions on yielding parameters, chemical compositions and baking quality of ancient wheat species Triticum monococcum L., Triticum dicoccum Schrank and Triticum spelt L. in comparison with modern Triticum aestivum L. Arch. Agron. Soil Sci. 2019, 65, 152-163. [CrossRef]

11. Wanic, M.; Denert, M.; Treder, K. Effect of forecrops on the yield and quality of common and spelt wheat grain. J. Elem. 2019, 24, 369-383. [CrossRef]

12. Dunwell, J.M. Haploids in flowering plants: Origins and exploitation. Plant Biotechnol. J. 2010, 8, 377-424. [CrossRef] [PubMed]

13. Germana, M.A. Gametic embryogenesis and haploid technology as valuable support to plant breeding. Plant Cell Rep. 2011, 30, 839-857. [CrossRef] [PubMed] 
14. Hensel, G.; Oleszczuk, S.; Daghma, D.E.S.; Zimny, J.; Melzer, M.; Kumlehn, J. Analysis of T-DNA integration and generative segregation in transgenic winter triticale ( $\times$ Triticosecale Wittmack). BMC Plant Biol. 2012, 12, 171. [CrossRef]

15. Niu, Z.; Jiang, A.; Abu Hammad, W.; Oladzadabbasabadi, A.; Xu, S.S.; Mergoum, M.; Elias, E.M. Review of doubled haploid production in durum and common wheat through wheat $\times$ maize hybridization. Plant Breed. 2014, 133, 313-320. [CrossRef]

16. Shchukina, L.V.; Pshenichnikova, T.A.; Khlestkina, E.K.; Misheva, S.; Kartseva, T.; Abugalieva, A.; Borner, A. Chromosomal location and mapping of Quantitaive Trait Locus determining technological parameters of grain and flour in strong-flour bread wheat cultivar Saratovskaya 29. Cereal Res. Commun. 2018, 46, 628-638. [CrossRef]

17. Sharma, P.; Chaudhary, H.K.; Manoj, N.V.; Kumar, P. New protocol for colchicine induced efficient doubled haploidy in haploid regenerants of tetraploid and hexaploid wheats at in vitro level. Cereal Res. Commun. 2019, 47, 356-368. [CrossRef]

18. Testillano, P.S. Microspore embryogenesis: Targeting the determinant factors of stress-induced cell reprogramming for crop improvement. J. Exp. Bot. 2019, 70, 2965-2978. [CrossRef]

19. Kalinowska, K.; Chamas, S.; Unkel, K.; Demidov, D.; Lermontova, I.; Dresselhaus, T.; Kumlehn, J.; Dunemann, F.; Houben, A. State-of-the-art and novel developments of in vivo haploid technologies. Theor. Appl. Genet. 2019, 132, 593-605. [CrossRef]

20. Schmid, J. In Vitro Production of Haploids in Triticum Spelta. In Biotechnology and in Agriculture and Forestry-13 Wheat; Bajaj, Y.P.S., Ed.; Springer: Berlin/Heidelberg, Germany, 1990; pp. 363-381.

21. Escarnot, E.; Thibaut, C.; Forgeois, P. Study of the impact of growth substance treatment and maize (Zea mays L.) variety in spelt (Triticum spelta L.) haplodiploidization. Biotechnol. Agron. Soc. 2014, 18, 32-36.

22. Lantos, C.; Jenes, B.; Bona, L.; Cserhati, M.; Pauk, J. High frequency of doubled haploid plant production in spelt wheat. Acta Biol. Cracov. Bot. 2016, 58, 107-112. [CrossRef]

23. Lantos, C.; Bona, L.; Nagy, E.; Bekes, F.; Pauk, J. Induction of in vitro androgenesis in anther and isolated microspore culture of different spelt wheat (Triticum spelta L.) genotypes. Plant Cell Tiss. Org. 2018, 133, 385-393. [CrossRef]

24. Castillo, A.M.; Allue, S.; Costar, A.; Alvaro, F.; Valles, M.P. Doubled Haploid Production from Spanish and Central European Spelt by Anther Culture. J. Agric. Sci. Tech. Iran 2019, 21, 1313-1324.

25. Esteves, P.; Belzile, F. Improving the efficiency of isolated microspore culture in six-row spring barley: I-optimization of key physical factors. Plant Cell Rep. 2014, 33, 993-1001. [CrossRef]

26. Esteves, P.; Clermont, I.; Marchand, S.; Belzile, F. Improving the efficiency of isolated microspore culture in six-row spring barley: II-exploring novel growth regulators to maximize embryogenesis and reduce albinism. Plant Cell Rep. 2014, 33, 871-879. [CrossRef]

27. Ahmadi, B.; Ahmadi, M.; Teixeira da Silva, J.A. Microspore embryogenesis in Brassica: Calcium signalling, epigenetic modification, and programmed cell death. Planta 2018, 248, 1339-1350. [CrossRef]

28. Takacs, I.; Kovacs, G.; Barnabas, B. Analysis of the genotypic effect on different developmental pathways in gametophyte cultures. Plant Cell Rep. 1994, 13, 227-230.

29. Pauk, J.; Mihaly, R.; Puolimatka, M. Protocol of wheat (Triticum aestivum L.) anther culture. In Doubled Haploid Production in Crop Plants. A Manual; Maluszynski, M., Kasha, K.J., Forster, B.P., Szarejko, I., Eds.; Kluwer Academic Publishers: Dordrecht, The Netherlands, 2003; pp. 59-64.

30. Jauhar, P.P.; Xu, S.S.; Baezinger, P.S. Haploidy in cultivated wheats: Induction and utility in basic and applied research. Crop Sci. 2009, 49, 737-755. [CrossRef]

31. Kumari, M.; Clarke, H.J.; Small, I.; Siddique, K.H.M. Albinism in Plants: A major bottleneck in wide hybridization, androgenesis and doubled haploid culture. Crit. Rev. Plant Sci. 2009, 28, 393-409. [CrossRef]

32. Broughton, $\mathrm{S}$. The application of n-butanol improves embryo and green plant production in anther culture of Australian wheat (Triticum aestivum L.) genotypes. Crop Pasture Sci. 2011, 62, 813-822. [CrossRef]

33. Krzewska, M.; Czyczylo-Mysza, I.; Dubas, E.; Golebiowska-Pikana, G.; Zur, I. Identification of QTLs associated with albino plant formation and some new facts concerning green and albino ratio determinants in triticale ( $\times$ Triticosecale Wittm.) anther culture. Euphytica 2015, 206, 263-278. [CrossRef]

34. Makowska, K.; Oleszczuk, S. Albinism in barley androgenesis. Plant Cell Rep. 2014, 33, 385-392. [CrossRef]

35. Holme, I.B.; Olesen, A.; Hansen, N.J.P.; Andersen, S.B. Anther and isolated microspore culture response of wheat lines from northwestern and eastern Europe. Plant Breed. 1999, 118, 111-117. [CrossRef] 
36. Tuvesson, S.; Ljungberg, A.; Johansson, N.; Karlsson, K.E.; Suijs, L.W.; Josset, J.P. Large-scale production of wheat and triticale double haploids through the use of a single-anther culture method. Plant Breed. 2000, 119, 455-459. [CrossRef]

37. Yildrim, M.; Bahar, B.; Genc, I.; Hatipoglu, R.; Altintas, S. Reciprocal effects in anther cultures of wheat hybrids. Biol. Plant. 2008, 52, 779-782. [CrossRef]

38. Lazar, M.D.; Baenziger, P.S.; Schaeffer, G.W. Combining abilities and heritability of callus formation and plantlet regeneration in wheat (Triticum aestivum L.) anther cultures. Theor. Appl. Genet. 1984, 68, 131-134. [CrossRef]

39. Ouyang, J.W.; Jia, S.E.; Zhang, C.; Chen, X.; Fen, G. Annual Report, A New Synthetic Medium $\left(W_{14}\right)$ for Wheat Anther Culture; Institute of Genetics, Academia Sinica: Beijing, China, 1989; pp. 91-92.

40. Lantos, C.; Pauk, J. Anther culture as an effective tool in winter wheat (Triticum aestivum L.) breeding. Russ. J. Genet. 2016, 52, 794-801. [CrossRef]

41. AACC International. Approved Methods of Analysis, 11th ed.; Method 55-31; Single-Kernel Characterization System for Wheat Kernel Texture AACCI; Cereals \& Grains Association: St. Paul, MN, USA, 2010.

42. Griffing, J.B. Concept of general and specific combining ability in relation to diallel crossing system. Aust. J. Biol. Sci. 1956, 9, 463-493. [CrossRef]

(C) 2019 by the authors. Licensee MDPI, Basel, Switzerland. This article is an open access article distributed under the terms and conditions of the Creative Commons Attribution (CC BY) license (http://creativecommons.org/licenses/by/4.0/). 